\title{
BTK Inhibitor M7583
}

National Cancer Institute

\section{Source}

National Cancer Institute. BTK Inhibitor M7583. NCI Thesaurus. Code C129710.

An orally bioavailable, selective inhibitor of Bruton's tyrosine kinase (BTK), with potential antineoplastic activity. Upon administration, M7583 targets and covalently binds to BTK, thereby preventing its activity. This leads to an inhibition of $B$ cell receptor (BCR) signaling and inhibits cell proliferation of B-cell malignancies. BTK, a cytoplasmic tyrosine kinase and member of the Tec family of kinases, plays an important role in B lymphocyte development, activation, signaling, proliferation and survival. 